\title{
IMPACTS OF SALT STRESS ON THE PHYSIOLOGY OF PLANTS AND OPPORTUNITY TO REWATER THE STRESSED PLANTS WITH DILUTED WATER: A REVIEW
}

\author{
JAVED, Q. ${ }^{1}-$ AZEEM, A. ${ }^{1}-$ SUN, J. ${ }^{1 *}-$ ULLAH, I. ${ }^{2}-$ JABRAN, K. ${ }^{3}-$ ANANDKUMAR, A. ${ }^{1}-$ \\ PRABAKARAN, K. ${ }^{1}-$ BUTTAR, N. A. $^{2}-$ DU, D. ${ }^{1,2^{*}}$ \\ ${ }^{1}$ Institute of Environment and Ecology, Academy of Environmental Health and Ecological \\ Security, School of the Environment and Safety Engineering, Jiangsu University, Zhenjiang \\ 212013, China \\ ${ }^{2}$ Key Laboratory of Modern Agricultural Equipment and Technology, Ministry of Education, \\ Institute of Agricultural Engineering, Jiangsu University, Zhenjiang, Jiangsu, China \\ ${ }^{3}$ Department of Plant Production and Technologies, Faculty of Agricultural Sciences and \\ Technologies, Nĭ̆ge Ömer Halisdemir University, Niğde, Turkey \\ *Corresponding authors \\ e-mail:ddl@ujs.edu.cn (D.L.Du),zxsjf@ujs.edu.cn (J.F.Sun) \\ (Received $12^{\text {th }}$ May 2019; accepted $16^{\text {th }}$ Jul 2019)
}

\begin{abstract}
Water scarcity on a global scale declines the availability of fresh water for agricultural usage. This situation demands the urgent need of utilizing saline water as an alternative resource for irrigation. Stressful environments characterized by adverse natural conditions such as drought, salinity and heat impact the normal molecular, biochemical and physiological processes in crops. Plant stress responses to adverse environmental conditions are reviewed with emphasis on growth, physiological and electrophysiological mechanisms of plant tolerance. This review may also help in interdisciplinary studies to evaluate the photosynthetic threshold levels for rewatering of plant with diluted saline water. Furthermore, considering the goal of high plant production, the best rewatering time was found when plants undergo threshold levels. Therefore, this review provides a new method for dilution of saline irrigation based on plant physiology, which has a huge practical and theoretical importance for saline irrigation research.
\end{abstract}

Keyword: photosynthetic traits, growth properties, plant tolerance, rewatering time, threshold levels

\section{Introduction}

Salinity is a major abiotic constraint curtailing crop growth and yield all over the world. The soil salinity is a widespread global concern caused as a result of abundant seawater intrusion in coastal areas, occurrence of saline groundwater and inadequate irrigation and/or drainage (Souza Filho et al., 2003; Nadeem et al., 2014; Yepes et al., 2018). Salinity induced stress in crop plants is a severe environmental problem in many parts of the world, particularly arid and semi-arid (i.e., dry) regions (Rady et al., 2018). Increasing soil salinity issues in some parts of the arid and semi arid regions is due to the inadequate drainage facilities which obliges the use of poor-quality water for irrigation, which may cause $30 \%$ shrink in cultivable land within the next 25 years (Shahbaz and Ashraf, 2013). In the present scenario, the adverse effects of land salinization become evident for the fact that over $30 \mathrm{~m}$ ha of irrigated lands are significantly damaged by the salt build up and about $0.5 \mathrm{~m}$ ha are reported to be lost from farming annually (Singh, 2018). Salinity poses adverse effects to almost all growth stages and metabolic processes in plants starting from a reduction in seed germination, a 
disruption of node formation, a retardation of plant development and finally ending up with a reduction in final crop yield (Munns and Tester, 2008). This reduction in crop yield will pose a severe threat to the global food security as the world populace is estimated to reach between 9 and 10 billion in 2050 (Lutz et al., 2017). Therefore, in order to feed the burgeoning world populace, sustainable irrigation practices should be adopted that improve the existing salinised agricultural lands (Flowers and Yeo, 1995; Biswas, 2008; Garcia, 2008).

Water scarcity and salinity are two major constraints which affect the agricultural production all over the world and the adoption of different irrigation regimes is the key requisite to improve water use efficiency in agricultural practices (Nangare et al., 2016; Mosaffa and Sepaskhah, 2018). Therefore, knowledge on the understanding of the physiological responses that define the plants' tolerance to surpass salinity stress is essential. By understanding the mechanism of the plants' stress tolerance, it is possible to develop water efficient irrigation regimes for agricultural activities (Zhang et al., 2011). Water saving agriculture is an effective approach to manage the ever increasing demand for food. Practically, this is achieved by amendments in different technological disciplines such as agronomy, biology and engineering. The engineering approaches include efficient utilization of existing water resources, water desalinization, and usage of brackish water or recycled sewage water for agricultural purposes. Meanwhile, agronomic and plant biology approaches include a wide range of innovative methods such as crop rotation, water conservation, water-fertilizer combination, physiological responses of plants, crop management and vegetative growth (Du et al., 2014, 2015).

In case of water scarcity, diluted saline water becomes the inevitable source for irrigation of plants. However, to ensure the safe use of saline water, effective crop management strategies are required to be developed in order to understand the response of crops to salinity (Bustan et al., 2004; Azeem et al., 2017a). The use of diluted saline water as an alternative resource for fresh water to irrigate the moderately salt tolerant crops will reduce irrigation cost, sustain agricultural productivity and save water resources. Thus, this comprehensive review aims to focus on the effect of rewatering or dilution of salted water on the photosynthetic responses in plants growing under saline stress (Fig. 1). Furthermore, this review emphasized the restoring abilities of plants from salt stress after re-watering or dilution of salted water.

\section{Physiological response of plants to salt stresses}

\section{Photosynthetic characteristics}

Salinity stress obstructs the physiological processes of plants (Negrão et al., 2017). It imposes a severe impact on the photosynthetic activity of plants (Sayed, 2003; Ashraf and Shahbaz, 2003; Kao et al., 2006; Munira et al., 2015; Habib et al., 2012; Hu et al., 2009). Photosynthesis is the most essential and complex functional process in all plants and a key factor in the development of plants. The stress induced by salinity impacts the overall capacity of photosynthesis (Ashraf and Harris, 2013). During salinity exposure, plants experience changes in photosynthetic characteristics, including transpiration rate $\left(T_{R}\right)$, relative leaf water content (Lee et al., 2005) and photosynthetic pigments (Tort and Turkyilmaz, 2004; Murillo-Amador et al., 2007; Taffouo et al., 2010; Javed et al., 2017). However, the regulation of photosynthesis is being distressed through stomata limitation, thereby reducing $\mathrm{T}_{\mathrm{R}}$ and leaf water potential $\left(\Psi_{\mathrm{L}}\right)$ (Azevedo Neto et al., 2004; Azeem et al., 2017b). 


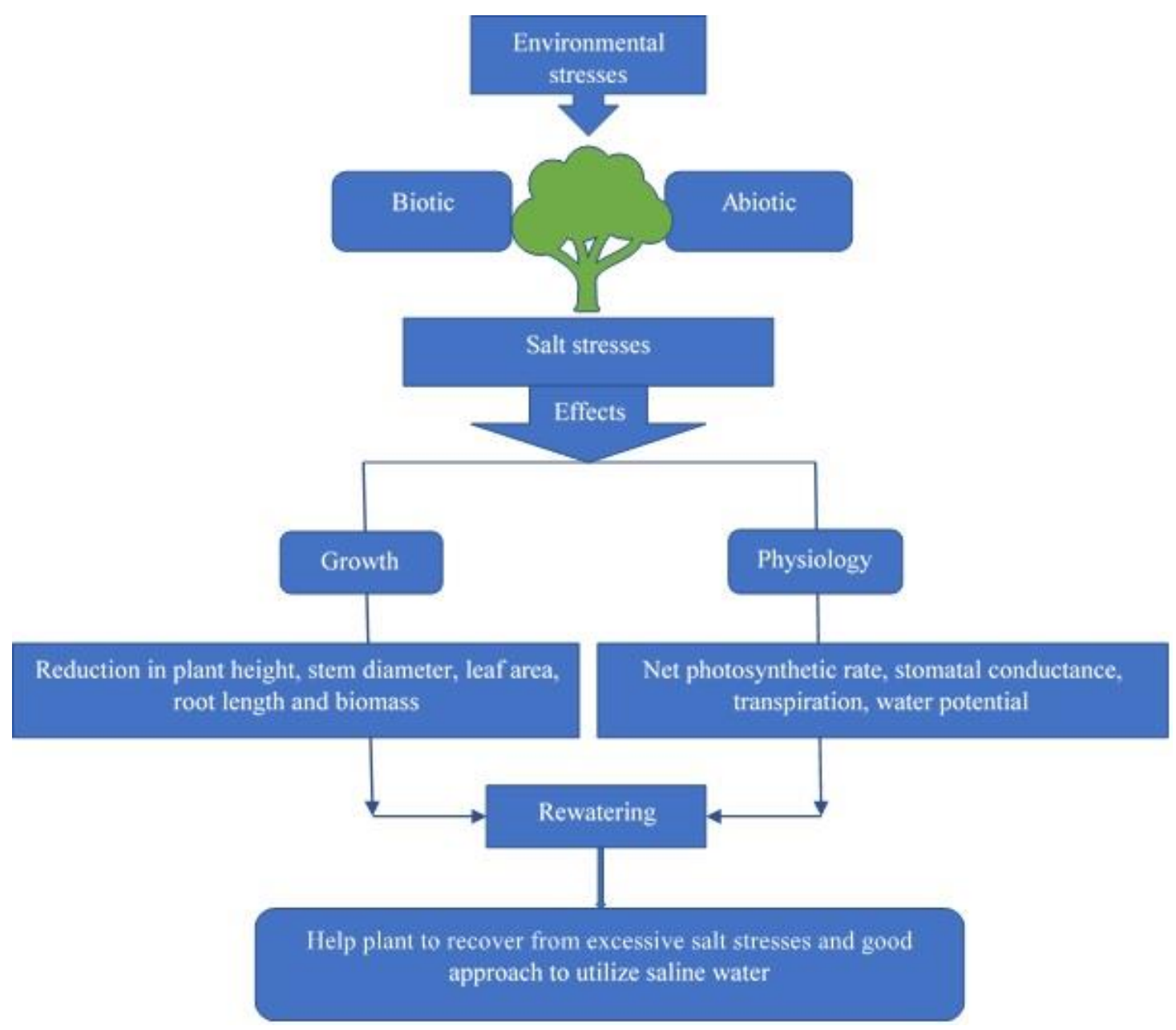

Figure 1. Graphical representation of salt stress on plant and afterwards rewatering effects

Stresses in plants inhibit the net photosynthetic rate $\left(P_{N}\right)$ through stomatal openingclosing restrictions (Saibo et al., 2009; Rahnama et al., 2010), particularly in the case of green plants. Salt-stress in the leaves of tomato plants is increased through increased $\mathrm{Na}^{+}$concentration (Ullah et al., 2017). Salt stress of $>80 \mathrm{mM}$ of $\mathrm{NaCl}$ strongly inhibited the $P_{N}$ and stomata conductance $\left(\mathrm{S}_{\mathrm{g}}\right)$. This indicated that the high salt concentration exhibited toxicity in the leaves of tomatoes, which is the main reason of reduction of $\mathrm{S}_{\mathrm{g}}$ and $P_{N}$ under high-stress (> $80 \mathrm{mM}$ of $\mathrm{NaCl}$ ) (Wang et al., 2011a). Limitation in $S_{g}$ has been recorded usually at early stages of drought-stress, which in turn increases the water use efficiency (WUE). Stomatal closure has more inhibitory results on transpiration than diffusion of $\mathrm{CO}_{2}$ into the leaf tissues (Sikuku et al., 2010). Though in comparison, under severe-stress dehydration takes place in mesophyll cells and initiating marked inhibition of necessary photosynthetic metabolic process as well as reduces WUE of plants (Damayanthi et al., 2011; Anjum et al., 2011). Yousif et al. (2010) examined the salt-tolerance difference mechanisms between water spinach (Ipomoea aquatica L.) and New Zealand spinach (Tetragonia tetragonoides). The $P_{N}$, $\mathrm{S}_{\mathrm{g}}$ and $\mathrm{T}_{\mathrm{R}}$ of both species are reduced with increasing salt-stress, but $P_{N}, \mathrm{~S}_{\mathrm{g}}$ and $\mathrm{T}_{\mathrm{R}}$ in New Zealand spinach are maintained at $100 \mathrm{mM} \mathrm{NaCl}$ than in water spinach. Chartzoulakis et al. (2002a) observed the salt-stress caused by varying concentrations of $\mathrm{NaCl}(0,25,50,100$ and $200 \mathrm{mM})$ on the growth and photosynthetic traits of six olive 
cultivars (Kalamata, Koroneiki, Mastoidis, Amphissis, Megaritiki and Kothreiki). The $P_{N}$ and $\mathrm{S}_{\mathrm{g}}$ of fully prolonged young leaves of all cultivars were reduced significantly at high concentrations of salinity $>100 \mathrm{mM}$. In all species, Kalamata showed the higher tolerance to salt stress at $100 \mathrm{mM} \mathrm{NaCl}$, followed by Megaritiki and Kothreiki. Effects of abiotic stresses on plant physiology and their corresponding threshold values are shown in Table 1.

Table 1. Effect of stresses on photosynthetic characteristics and their corresponding threshold values

\begin{tabular}{|c|c|c|c|c|c|c|c|}
\hline Stress & Plant species & Concentrations & 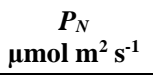 & 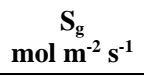 & $\begin{array}{c}\mathrm{T}_{\mathrm{R}} \\
\mathbf{m m o l} \mathbf{m}^{2} \mathbf{s}^{-1}\end{array}$ & $\begin{array}{c}\text { Threshold } \\
\text { levels }\end{array}$ & Resources \\
\hline \multirow{4}{*}{$\begin{array}{l}\text { Salt-stress } \\
\qquad \mathrm{NaCl} \\
(\mathrm{mM})\end{array}$} & \multirow{4}{*}{$\begin{array}{l}\text { New Zealand } \\
\text { spinach } \\
\text { (Tetragonia } \\
\text { tetragonoides) }\end{array}$} & 0 & 22.5 & 1.3 & 6.6 & $=100$ & \multirow{4}{*}{$\begin{array}{c}\text { Yousif et al., } \\
2010\end{array}$} \\
\hline & & 50 & 16.9 & 0.4 & 2.6 & & \\
\hline & & 100 & 15.7 & 0.2 & 1.8 & $=200$ & \\
\hline & & 200 & 8.7 & 0.1 & 1.1 & & \\
\hline \multirow{4}{*}{$\begin{array}{l}\text { Salt-stress } \\
\qquad \mathrm{NaCl} \\
(\mathrm{mM})\end{array}$} & \multirow{4}{*}{$\begin{array}{l}\text { Water spinach } \\
\text { (Ipomoea } \\
\text { aquatica L.) }\end{array}$} & 0 & 21.0 & 0.6 & 3.3 & $=<100$ & \multirow{4}{*}{$\begin{array}{c}\text { Yousif et al., } \\
2010\end{array}$} \\
\hline & & 50 & 11.9 & 0.1 & 1.4 & & \\
\hline & & 100 & 10.7 & 0.08 & 0.9 & $=200$ & \\
\hline & & 200 & 0 & 0 & 0 & & \\
\hline \multirow{4}{*}{$\begin{array}{l}\text { Salt-stress } \\
\qquad \mathrm{NaCl} \\
(\mathrm{mM})\end{array}$} & \multirow{4}{*}{ Tomato } & 40 & 10 & 0.10 & 2.0 & $=<120$ & \multirow{4}{*}{$\begin{array}{c}\text { Wang et al., } \\
2011 \mathrm{~b}\end{array}$} \\
\hline & & 80 & 7.8 & 0.07 & 1.8 & & \\
\hline & & 120 & 6.0 & 0.05 & 1.5 & $>120$ & \\
\hline & & 160 & 5.0 & 0.04 & 1.45 & & \\
\hline \multirow{4}{*}{$\begin{array}{l}\text { Salt-stress } \\
\text { Ec }\left(\mathrm{dsm}^{-1}\right)\end{array}$} & \multirow{4}{*}{$\begin{array}{c}\text { Brassica } \\
\text { juncea } \mathrm{L} . \\
\text { (Varuna) }\end{array}$} & 0 & 20 & 0.07 & 3.2 & $=4.2$ & \multirow{4}{*}{$\begin{array}{c}\text { Wani et al., } \\
2013\end{array}$} \\
\hline & & 2.8 & 16 & 0.04 & 27 & & \\
\hline & & 4.2 & 14 & 0.03 & 2.5 & $=5.6$ & \\
\hline & & 5.6 & 13 & 0.03 & 2.4 & & \\
\hline \multirow{4}{*}{$\begin{array}{l}\text { Salt-stress } \\
\text { Ec }\left(\mathrm{dsm}^{-1}\right)\end{array}$} & \multirow{4}{*}{$\begin{array}{c}\text { Brassica } \\
\text { juncea } \text { L. (RH- } \\
\text { 30) }\end{array}$} & 0 & 17 & 0.057 & 3.0 & $=<4.2$ & \multirow{4}{*}{$\begin{array}{c}\text { Wani et al., } \\
2013\end{array}$} \\
\hline & & 2.8 & 11 & 0.028 & 2.3 & & \\
\hline & & 4.2 & 9 & 0.025 & 2.0 & $>4.2$ & \\
\hline & & 5.6 & 7 & 0.02 & 1.7 & & \\
\hline \multirow{4}{*}{$\begin{array}{c}\text { Deficit } \\
\text { irrigation } \\
\text { ETc }(\%)\end{array}$} & \multirow{4}{*}{$\begin{array}{c}\text { Cabbage } \\
\text { (Brassica } \\
\text { oleracea L.) }\end{array}$} & 50 & & & 10 & $=75$ & \multirow{4}{*}{$\begin{array}{c}\mathrm{Xu} \text { and } \\
\text { Leskovar, 2014 }\end{array}$} \\
\hline & & 75 & 18.6 & 0.357 & 12.1 & & \\
\hline & & 100 & 21.6 & 0.472 & 14.4 & $=50$ & \\
\hline & & & 23.6 & 0.673 & & & \\
\hline \multirow{3}{*}{$\begin{array}{l}\text { Drought stress } \\
\quad(\text { FC \%) }\end{array}$} & \multirow{3}{*}{$\begin{array}{c}\text { Medicago } \\
\text { laciniata } \\
\text { saharian (Ml- } \\
90)\end{array}$} & 100 & 9.2 & 0.17 & 3.0 & $=75$ & \multirow{3}{*}{$\begin{array}{c}\text { Yousfi et al., } \\
2016\end{array}$} \\
\hline & & 75 & 6.3 & 0.11 & 1.8 & & \\
\hline & & 35 & 4 & 0.07 & 1.6 & $=35$ & \\
\hline \multirow{4}{*}{$\begin{array}{l}\text { Drought stress } \\
\text { (days of } \\
\text { withheld } \\
\text { irrigation) }\end{array}$} & \multirow{4}{*}{$\begin{array}{c}\text { Astragalus } \\
\text { gombiformis } \\
\text { Pomel }\end{array}$} & 5 & 5.41 & 0.232 & 4.09 & $=15$ & \multirow{4}{*}{$\begin{array}{c}\text { Boughalleb et } \\
\text { al., 2016a }\end{array}$} \\
\hline & & 10 & 5.61 & 0.229 & 4.00 & & \\
\hline & & 15 & 5.04 & 0.205 & 3.58 & $=20$ & \\
\hline & & 20 & 4.95 & 0.171 & 3.19 & & \\
\hline \multirow{9}{*}{$\begin{array}{l}\text { Irrigation water } \\
\text { salinity }\end{array}$} & & 2 & 17.0 & 0.43 & 6.0 & & \\
\hline & $\begin{array}{l}\text { Barley cultivar } \\
\text { [Morocco] }\end{array}$ & 10 & 15.0 & 0.25 & 7.5 & $=10$ & $\begin{array}{c}\text { Mahlooj1 et al., } \\
2018\end{array}$ \\
\hline & & 18 & 7.0 & 0.18 & 4.0 & & \\
\hline & & 2 & 16.0 & 0.38 & 6.9 & & \\
\hline & $\begin{array}{c}\text { Barley cultivar } \\
\text { [Nosrat] }\end{array}$ & 10 & 24.5 & 0.27 & 8.5 & $>10<18$ & \\
\hline & & 18 & 14.2 & 0.25 & 6.7 & & \\
\hline & & 2 & 22.0 & 0.35 & 5.8 & & \\
\hline & $\begin{array}{c}\text { Barley cultivar } \\
\text { [Khatam] }\end{array}$ & 10 & 19.4 & 0.28 & 7.4 & $=18$ & \\
\hline & & 18 & 19.2 & 0.26 & 5.5 & & \\
\hline
\end{tabular}

$P_{N}$ is net photosynthetic rate; $\mathrm{S}_{\mathrm{g}}$ is stomatal conductance; $\mathrm{T}_{\mathrm{R}}$ is transpiration 
Stomatal closure is one of the instant responses to water-stress. Generally the atmospheric vapor pressure and leaf turgor pressure can be disturbed because of reduction in stomatal opening in response to drought and salinity stress (Chaves et al., 2009; Javed et al., 2018). Therefore, reduction in $P_{N}$ under traumatic conditions like drought, temperature, and salinity, is normally due to suppression in the mesophyll cells and stomatal opening-closing limitation (Flexas et al., 2004; Azeem et al., 2017a).

The research by Boughalleb et al. (2016a) on Astragalus gombiformis Pomel, found that $P_{N}, \mathrm{~S}_{\mathrm{g}}, \mathrm{T}_{\mathrm{R}}$, and internal $\mathrm{CO}_{2}$ concentration $(\mathrm{Ci})$ was decreased significantly with water-stress duration as compared to that of well watered conditions. A Cerrado's native plant, Campomanesia adamantinum (C. adamantium) $\mathrm{O}$. Berg, has a potential to exhibit stress tolerant abilities. It is susceptible to grow in an atmosphere of high temperature, dry land and water deficit region. During the experimental period, the photosynthetic factors are evaluated for $C$. adamantium. Seedlings are more stable for plants under control condition, and vast variations are noted in stress subjected plants. At the thirtyfirst day of water-deficit, $S_{\mathrm{g}}$ and $\mathrm{T}_{\mathrm{R}}$ are reduced and $P_{N}$ approaches to zero as $0.2851 \mathrm{~mol} \mathrm{~m}^{-2} \mathrm{~s}^{-1}$. Consequently, WUE also reaches close to zero. Subsequently, the plants are rewatered to recover the photosynthetic metabolic activity (Junglos et al., 2016). Further, the threshold levels of photosynthetic capacity is explained by the extent to which the plants can withstand the stress imposed on the different features of photosynthesis, which can subsequently be used for rewatering of plants to regain the photosynthetic capacity affected by stresses.

\section{Leaf water potential and carbonic anhydrase activity}

The leaf water potential $\left(\Psi_{\mathrm{L}}\right)$ is termed as the energy status of water in the leaves. The comparative activity of $S_{\mathrm{g}}$ and $P_{N}$ regulation is directed to water-use efficiency (Vos and Groenwold, 1989) and leaf water potential (Wani et al., 2013). Leaf water potential or leaf water status is a major factor affecting overall behavior and performance of stomata (Ruiz-Sýnchez et al., 1988). Salt-stress inhibits photosynthesis process by lowering $\Psi_{\mathrm{L}}$ (Parida and Das, 2005). Gorai et al. (2010) stated that limited supply of water reduced the dry weight of whole-plant, with a reduction in relative water content and $\Psi_{\mathrm{L}}$. In certain studies, salt-stressed plants exhibit osmotic regulation due to changes in leaf water status (Kaymakanova and Stoeva, 2008; Gama et al., 2009). Among the different physiological parameters recommended to indicate waterstatus of vine, $\Psi_{\mathrm{L}}$ has been considered more feasible (Baeza et al., 2007) rather than $S_{g}$ (Cifre et al., 2005) and temperature of leaf canopy (Bernard et al., 2004). However, there still exists some uncertainity as to which time plant shows the best water status, and what time of the day is optimum for measuring the water potential. (Deloire et al., 2004), used predawn $\Psi_{\mathrm{L}}$ as a standard to assess water-status at different stages of plants development in France. In Portugal, (Lopes, 1998), attained a very close relationship between $P_{N}$ and predawn $\Psi_{\mathrm{L}}$ under water-stress conditions. Sato et al. (2006) checked the validity of predawn $\Psi_{\mathrm{L}}$ as an indicator for irrigation of wheat in northern Syria. Whereas, Intrigliolo et al. (2004) and Salón et al. (2005) measured $\Psi_{\mathrm{L}}$ during daylight and found that $\Psi_{\mathrm{L}}$ at mid-morning or at noon seem to execute the water-status better than predawn $\Psi_{\mathrm{L}}$.

Williams and Araujo (2002) described that the measurements of plant water status are associated with plant physiology. According to Xiloyannis et al. (1997), olive plants (Olea europaea) adopt different strategies to survive under water-stress conditions as: (i) by lowering their $\Psi_{\mathrm{L}}$ and water content (WC) of leaf tissues, and then use soil water 
up to $-2.5 \mathrm{MPa}$; (ii) plants stop shoot's growth but not its $P_{N}$ activity; (iii) adjustment of osmotic pressure, which is found to show a significant part in maintaining leaf cell activities. Generally, good positive relationships are found between $S_{\mathrm{g}}, \Psi_{\mathrm{L}}$ and growth of plants. The growth of New Zealand spinach (Tetragonia tetragonoides) showed a notable reduction in $\Psi_{\mathrm{L}}$ and osmotic potential with increasing salinity. Water spinach showed tolerance and survived up to $-1.99 \mathrm{Mpa}$ (Yousif et al., 2010). Plant water status and stem water potential are used as indicators for irrigation scheduling, which requires the description of reference values or threshold values, in order to acheive the optimum irrigation levels. Depending on the response of plants in relationship with $\Psi_{\mathrm{L}}$ and $\mathrm{WC}$, the obtained threshold values are -1.04 and $-1.46 \mathrm{MPa}$, respectively for irrigation of apple varieties i.e., Mutsu and CoxOrange (De Swaef et al., 2009). Increasing salinity reduces the osmotic potential of the bean plants. This variation is considered as one of the defensive mechanism of plants to tolerate stresses. The values noticed indicate an inverse relationship between osmotic potential and salt stress in bean leaves. The statistical analysis revealed that the decline in osmotic potential is significant with increased $\mathrm{NaCl}$ concentration > $120 \mathrm{Mm}$ (Qados, 2011).

A decline in water potential was noticed as a result of reducing relative WC (Kalapos, 1994; Bhatt et al., 2008). Therefore, some plants could convert intracellular $\mathrm{HCO}_{3}{ }^{-}$into $\mathrm{CO}_{2}$ and $\mathrm{H}_{2} \mathrm{O}$ by carbonic anhydrase activity (CA) to maintain water content. Carbonic anhydrase activity (CA) is very important in biological functions of plants that include reactions of carboxylation and decarboxylation and it is also takes part in the transporting of inorganic $\mathrm{CO}_{2}$ to active photosynthetic cells (Henry, 1996). $\mathrm{CA}$ is a zinc containing enzyme activity, and is found in all living organisms. CA plays a dynamic role in assisting the transport of $\mathrm{CO}_{2}$ and protons in intracellular spaces and in the layers of the extracellular space, across cell membranes. It is also involved in several other processes like photosynthesis and respiration. CA catalyzes the rapid inter conversion of $\mathrm{HCO}_{3}{ }^{-}$into $\mathrm{CO}_{2}$ and $\mathrm{H}_{2} \mathrm{O}$. Meanwhile, CA activity is pretentious by deficiency of $\mathrm{Zn}$ and also takes part in sustaining the inorganic carbon levels (Tavallali et al., 2009). A reduction in CA activity caused by deficiency of $\mathrm{Zn}$ may contribute to the decrease in $P_{N}$ (Hacisalihoglu et al., 2003).

CA activity helps plants to prevent from losses of water under traumatic environmental conditions (Hu et al., 2011). Kicheva and Lazova (1998) elucidated the reduction of $\mathrm{CA}$ activity in wheat seedlings in response to slight osmotic-stress. However, it increased rapidly under severe osmotic-stress conditions. It is noted that wheat cultivars differ in their response to drought stress with different CA activities (Guliyev et al., 2008). CA activities varied with plant species, osmotic-stress levels and stress durations. CA activity is higher in Pharbitis nil (Linn.) Choisy (P. Nil) than Parthenocissus tricuspidata (Sieb. et Zucc.) (P. Tricuspidata) and Lonicera japonica Thunb (L. Japonica) under drought-stress. CA activity is undetectable in P. tricuspidata but for L. japonica, CA activity is lower under medium or high stress, than that of the stress under low level. With an increase in drought stress duration, CA activity sharply decreases (Xing and $\mathrm{Wu}, 2012$ ).

CA plays an important role in a number of physiological processes, such as maintaining acid-base balance, ion exchange, reactions of carboxylation and decarboxylation, and circulation of inorganic carbon between the cells (Table 2). CA regulates the photosynthetic mechanism in response to low stomata conductance (Wu and Xing, 2012). Xing and $\mathrm{Wu}$ (2015) examined the variations in CA activities with fluctuating nutrient levels for 3 -climber species. $P$. nil showed higher CA activity when 
compared with the other two species. While, P. tricuspidata showed the lowest and nearly undetectable CA activity. CA activity of $P$. nil under $1 / 2$ and $1 / 4$ strength nutrient solutions, is slightly higher than those under $1 / 16$ and $1 / 32$ strength nutrient solution. For L. japonica, CA activity is lower under control (full-strength nutrient solution) than those which are concealed under 1/4,1/8,1/16 and 1/32 strength nutrient solution. In previous studies, it is found that, by the regulation of CA activity $P_{N}$ increased in Orychophragmus violaceus (L.) O. E. Schulz (Orychophragmus violaceus) and it is observed as a shade tolerant crop in comparison of other Brassicaceae species (Wu et al., 2007; Wu et al., 2005). Therefore, water status in crop can be maintained by the regulation of CA activity. As a result, carbon and water source are provided for the photosynthesis process by the plant (Hu et al., 2011). Hence, CA activity deeds for the survival of plants under stressed environments (Wu et al., 2011).

This section emphasized on two key factors viz.,(1) the water status and water potential of stem and leaves to indicate the threshold values for irrigation or rewatering of plants; (2) the role of CA activity for regulation of photosynthesis against stressful environments.

Table 2. The role of CA activity during stress condition

\begin{tabular}{|c|c|c|c|}
\hline Plant species & Treatment & CA-activity role & Reference \\
\hline Okra & $\begin{array}{l}\text { Salt stress } \\
\mathrm{NaCl}+\mathrm{CaCl}_{2}\end{array}$ & $\begin{array}{l}\text { In moderate and low salt stress levels CA-activity play a } \\
\text { main role to maintain plant water status }\end{array}$ & $\begin{array}{l}\text { Azeem et al., } \\
2017 \mathrm{a}\end{array}$ \\
\hline $\begin{array}{l}\text { Orychophragmus } \\
\text { violaceus (L.) O. } \\
\text { E. Schulz and } \\
\text { Brassica napus } \\
\text { (L.) }\end{array}$ & $\begin{array}{l}\text { Salt stress } \\
\left(\mathrm{NaCl}, \mathrm{Na}_{2} \mathrm{SO}_{4}\right. \\
\left.\mathrm{NaCl}+\mathrm{Na}_{2} \mathrm{SO}_{4}\right)\end{array}$ & $\begin{array}{l}\text { The CA-activity in plants showed good regulatory and was } \\
\text { initially activated, when the leaves were under slight stress } \\
\text { levels. A substantial increase of CA-activity noted under } \\
\text { moderate-stress-levels. Due to regulation of CA-activity, } \\
\text { photosynthetic activity was increase and showed } \\
\text { development of growth parameters }\end{array}$ & $\begin{array}{l}\text { Javed et al., } \\
2018\end{array}$ \\
\hline $\begin{array}{c}\text { Broussonetia } \\
\text { papyrifera }(\mathrm{L} .) \\
\text { Vent. and Morus } \\
\text { alba } \mathrm{L} .\end{array}$ & $\begin{array}{l}\text { Salt stress } \\
\mathrm{NaHCO}_{3}\end{array}$ & $\begin{array}{c}\text { The stomatal opening and closing affected through variation } \\
\text { in leaf-water potential, initiating an imbalance in gaseous } \\
\text { exchange, and disturb the photosynthetic activity. To } \\
\text { overcome this situation, CA-activity is become activated in } \\
\text { leaves and providing partially carbon-water source to plants } \\
\text { suffering from shortage of water }\end{array}$ & $\begin{array}{l}\text { Wu and xing, } \\
2012\end{array}$ \\
\hline $\begin{array}{l}\text { Pharbitis nil } \\
\text { (Linn.) Choisy, } \\
\text { Lonicera japonica } \\
\text { Thunb. and } \\
\text { Parthenocissus } \\
\text { tricuspidata (Sieb. } \\
\text { et Zucc.) }\end{array}$ & $\begin{array}{l}\text { Nutrient deficit } \\
(1 / 2,1 / 4,1 / 8,1 / 16,1 / 32)\end{array}$ & $\begin{array}{l}\text { CA-activity was increasing with nutrient deficit and activate } \\
\text { when plant is going to stress due to nutrient deficit }\end{array}$ & $\begin{array}{l}\text { Xing and } \mathrm{Wu} \text {, } \\
2015\end{array}$ \\
\hline $\begin{array}{l}\text { Brassica napus } \\
\qquad(\text { L. })\end{array}$ & $\begin{array}{l}\text { Drought stress } \\
\text { (poly-ethylene glycol } 6000 \\
\text { (i.e. } 0,20,40 \text { and } 80 \mathrm{~g} \mathrm{~L}^{-1} \text { )) }\end{array}$ & $\begin{array}{c}\text { CA-activity is also activated in drought stress when duration } \\
\text { of drought was increasing. CA-activity helps plants during } \\
\text { drought stress for } \mathrm{H}_{2} \mathrm{O} \text { and } \mathrm{CO}_{2} \text { regulation and maintain its } \\
\text { growth }\end{array}$ & Xing et al., 2018 \\
\hline
\end{tabular}

CA activity is carbonic anhydrase activity

\section{Electrophysiological properties of plants}

Plants are subjected to several diverse abiotic stresses throughout the growing season in the field (Tester and Bacic, 2005). Toxic effects imposed by salt stress decreased the production of new leaves and inhibited leaf expansion (Mansour and Salama, 2004). In plants, salt tolerance is attributed by structural and functional variations, such as plant growth regulation, $\Psi_{\mathrm{L}}$ and osmotic adjustment. Water deficiency and its stability in plants can be described through its electrophysiological properties, in which, $\Psi_{\mathrm{L}}$ of a plant was reflected by WC, capacitance and leaf air temperature. 
A miniaturized, nondestructive sensor that employs a microwave micro strip ring resonator is developed for estimation of $\mathrm{WC}$ in single grain of wheat (Abraham et al., 2000) detected the amount of applied water/day, soil moisture content and leaf-air temperature based on electrical resistance. Koide (1991) revealed the relationship between $\Psi_{\mathrm{L}}$ with hydraulic resistance and capacitance of a plant. (Turner, 1988) used pressure chamber to calculte $\Psi_{\mathrm{L}}$. While, Zhang et al. (2015) suggested the rapid measurement of drought resistance in the leaves of Broussonetia papyrifera ( $B$. Papyrifera) and Morus alba (M. Alba) based on electrophysiological properties. A significant bonding is detected between physiological capacitance $\left(C_{p}\right)$, WC and $\Psi_{\mathrm{L}}$. The changes in physiological resistance and $C_{p}$, varied the water status in leaves (Table 3). Tensity of plant's leaf cell also can describe the status of water in leaf cells of plants, and that reflects the tolerance of plants to stress (Zhang et al., 2015). The outcomes of this review highlight the electrophysiological characteristics as rapid responses of plants to stress resistance. Furthermore, electrophysiological properties can be used to obtain precise information for irrigation and dilution of saline irrigation on the basis of water status in leaves.

Table 3. Plants responses due to variation in water potential, physiological capacitance and leaf tensity under salt stress and re-watering

\begin{tabular}{|c|c|c|c|c|c|}
\hline Plant species & $\begin{array}{c}\text { Salt } \\
\text { treatments }\end{array}$ & Effect & Re-watering effect & Mechanism & Reference \\
\hline $\begin{array}{l}\text { Okra } \\
\text { Abelmoschus } \\
\text { esculentus }\end{array}$ & $\begin{array}{c}\text { Salt stress } \\
(\mathrm{NaCl}+ \\
\left.\mathrm{CaCl}_{2}\right)\end{array}$ & $\begin{array}{c}\text { Salt stress in every level } \\
\text { reduces plant water potential } \\
\text { and physiological capacitance }\end{array}$ & $\begin{array}{c}\text { Recovery in the moderate } \\
\text { and slow salt levels but } \\
\text { could not recover in high } \\
\text { salt stress }\end{array}$ & $\begin{array}{c}\text { Plant stop to get water } \\
\text { from root zone because } \\
\text { of osmotic process }\end{array}$ & $\begin{array}{c}\text { Azeem et al., } \\
2017 b\end{array}$ \\
\hline $\begin{array}{l}\text { Orychophragmus } \\
\text { violaceus (L.) O. } \\
\text { E. Schulz and } \\
\text { Brassica napus } \\
\text { (L.) }\end{array}$ & $\begin{array}{l}\text { Salt stress } \\
(\mathrm{NaCl}+ \\
\left.\mathrm{Na}_{2} \mathrm{SO}_{4}\right)\end{array}$ & $\begin{array}{c}\text { Physiological capacitance and } \\
\text { leaf tensity of both species } \\
\text { decline with increasing } \\
\text { concentration of salts under } \\
\text { single salts effect and a } \\
\text { mixture of salts } \\
\end{array}$ & $\begin{array}{l}\text { Plant show better recovery } \\
\text { during re-watering in single } \\
\text { and mixture of salts, but } \\
\text { single salts recover well }\end{array}$ & $\begin{array}{l}\text { Due to excess amount } \\
\text { of salts, plant leaf } \\
\text { tissue loss the ability } \\
\text { to hold water }\end{array}$ & $\begin{array}{c}\text { Javed et al., } \\
2017\end{array}$ \\
\hline $\begin{array}{c}\text { Brassica napus } \\
\text { (L.) }\end{array}$ & $\begin{array}{c}\text { Drought } \\
\text { stress poly- } \\
\text { ethylene } \\
\text { glycol } 6000 \\
\text { (i.e. } 0,20,40 \\
\text { and } 80 \mathrm{~g} \mathrm{~L}^{-1} \text { ) }\end{array}$ & $\begin{array}{l}\text { Leaf water potential and } \\
\text { physiological capacitance are } \\
\text { decreased with increasing } \\
\text { drought stress level }\end{array}$ & $\begin{array}{c}\text { Re-water from } 40-0 \\
\text { recover better, but } 80-40 \\
\text { could not recover because } \\
\text { higher drought damage } \\
\text { plant leaf cell badly that } \\
\text { could not recover during } \\
\text { re-watering }\end{array}$ & $\begin{array}{l}\text { During drought } \\
\text { stomatal conductance } \\
\text { decreased and effect } \\
\text { the water regulation } \\
\text { and sustainability }\end{array}$ & $\begin{array}{l}\text { Xing et al., } \\
2018\end{array}$ \\
\hline
\end{tabular}

\section{Plant growth features}

Salinity is one of the key limiting factors affecting the physiological processes and its impacts may pose severe consequences on the growth of plants (Vilagrosa et al., 2003). The effect of salinity is different for different plant species and for different genotypes because plants exhibit unique tolerance mechanism (Memon et al., 2010; Gama et al., 2007). Salt stress inflicts biological disturbances in plants, causing adverse effects on plant growth, plant quality, and plant yield (Jouyban, 2012; Siddiqui et al., 2008; Qados, 2011). Mostly, species of brassica are considered to possess inbuilt salt tolerant mechanism because of their ability to cope up with salt-stress (Maggio et al., 2005; Hayat et al., 2007). This mechanism might be particularly significant with concerns for survival of salt tolerant plants. Previous studies point out the effects of salt stress on plant growth characteristics (Riccardi et al., 2014; Boughalleb et al., 2016b; Rameshwaran et al., 2016). Some researchers studied the relationship between the 
reduction in plant length by increasing the concentrations of $\mathrm{NaCl}$ (Mustard and Renault, 2006; Jamil et al., 2007; Rui et al., 2009). Certain other studies elucidated the toxic effect of $\mathrm{NaCl}$ concentrations on leaf characteristics (Netondo et al., 2004; Chen et al., 2007; Yilmaz and Kina, 2008). The harmful effect of salinity on the number of leaves per plant also increases with increasing concentration of salts. Numerous studies have focused on the effect of varying concentration of salts on fresh and dry weight of plants, either positively or negatively, which is dependent on the nature of salt present (Bayuelo-Jimenez et al., 2002b; Niazi et al., 2005; Turan et al., 2007; Taffouo et al., 2009, 2010).

Drought-salt resistance in plants is explained by structural and functional adaptations, such as osmotic adjustment, $\Psi_{\mathrm{L}}, \mathrm{S}_{\mathrm{g}}$ limitations and growth regulation (Zollinger et al., 2007). Plants undergo different changes from the very onset period of salinity stress till maturity periods (Munns, 2002). The variations in the plant development differ with differing time scales after salinization. Quick response of salinity to plants result in dehydration of plant's cells and cell shrinkage, but some hours later on there occurs the regaining of cell volume. But this mechanism affects the cell elongation and division and thereby impacting the plant root growth and leaf size (Läuchli and Grattan, 2007). Understanding these times dependent mechanism of plants in response to salinity, lead to the accomplishment of "two-phase" growth responses to salinity (Munns, 2005).

Salinity exceeding $6 \mathrm{dS} / \mathrm{m}$ causes constriction in the length of stem and impacts severe consequences on fruit quality (Carter et al., 2005). Among cultivars, there are even dissimilarities with respect to the tolerance mechanism (Ahmad et al., 2005) and these differences are not parallel with seasonal tolerance, as explained by Nerson and Paris (1984) for melon, Heenan et al. (1988) rice, Bayuelo-Jimenez et al. (2002a) bean and Tajbakhsh et al. (2006) barley. The best growth of Rhizophora mucronata Lam. is attained at $50 \%$ seawater, and a further rise in salinity beyond this level scales down the growth (Aziz and Khan, 2001). Experimental results demonstrated that in a salt-stress condition, the mangrove B. parviflora shows optimal growth performance at $100 \mathrm{mM}$ $\mathrm{NaCl}$, however a further increase in $\mathrm{NaCl}$ concentration retards the growth of plant. A concentration of about $500 \mathrm{mM} \mathrm{NaCl}$ was found to be lethal to mangrove plants (Parida et al., 2004). The mangrove Aegiceras corniculatum (L.) Blanco shows tolerance up to $250 \mathrm{mM} \mathrm{NaCl}$ and is found to be dead beyond this concentration (Mishra and Das, 2003). Increased concentration of $\mathrm{NaCl}$ results in a significant reduction of root/shoot ratio and leaf growth biomass (Meloni et al., 2001). There is an overall trend found for the increase in the plant's lengths of the Vicia faba L. by using the concentrations of $\mathrm{NaCl}, 60 \mathrm{mM}$ and $120 \mathrm{mM}$. More precisely, after treatment of 10 days, the increment is negatively correlated, by increasing $\mathrm{NaCl}$ concentration from 60 to $120 \mathrm{mM}$ and consequently, $40 \%$ death of the plants occurs at initial stage by using highest concentration of $240 \mathrm{mM} \mathrm{NaCl}$ (Qados, 2011). Contrary results are recorded as well, such as Dantas et al. (2005) on cowpea (Vigna unguiculata L.), and Memon et al. (2010) on Brassica campestris L., specified that the usage of low concentrations of $\mathrm{NaCl}$ causes an increase in plant's height, whereas high $\mathrm{NaCl}$ concentrations affected the growth of plants. Studies on moth bean (Vigna aconitifolia L.) (Mathur et al., 2006), radish plant (Raphanus sativus L.) (Jamil et al., 2007) and Vigna mungo L. (Kapoor and Srivastava, 2010) indicated that increased $\mathrm{NaCl}$ concentrations causes a decline in plant's length. 
In the light of the different tolerant mechanisms adopted by plants at their specific developmental stages against salinity, this review encompasses the reference levels or point for re-watering, the plants can endure after being exposed to salinity stress.

\section{Effects of rewatering on the physiology of plants}

\section{Recovery of physiological parameters by rewatering}

Photosynthetic responses to stresses are very complex and these include the chemistry of restrictions, taking place at diverse spots of leaf cell at different time periods in relation to the growth of plants (Boughalleb et al., 2016b). The stress intensity, duration and progression rate influence the plant responses to salinity and water shortage (Nohong and Nompo, 2015). These factors are associated with acclimation responses under drought stress, thereby affecting the photosynthetic rate indirectly. Under the influence of salinity, acclimation responses also include an adjustment in ion-transport such as uptake and extrusion of ions. These reactions are eventually clue to refurbishment of cellular homeostasis, shows survival of plants under stress (Chaves et al., 2009). Moreover, the carbon balance of plants during a period of water-stress and afterward regaining may depend as much on the recovery of $P_{N}$ (Flexas et al., 2006). Overall, the plant recovers 40 to $60 \%$ of maximum photosynthetic rate only after rewatering, when subjected to extreme water-stress, and recovery is continued through the next days, but maximum $P_{N}$ is not recovered always (Sofo et al., 2004). The strong influence of severe water-stress on $P_{N}$ and its recovery has been established by Miyashita et al. (2005), in kidney bean and has been recommended by (Gómez-delCampo et al., 2015), for Vitis vinifera L. plants.

Moreover, the recovery phase after stress release (e.g., irrigation or rewatering), becomes a major part of general plant biological responses to water-stress period. Recovery of the photosynthetic capability of plants from severe water-stress, defines the future growth development and survival of plants. Recently, this area is gaining much attention (Ennahli and Earl, 2005; Gallé et al., 2007; Xing et al., 2018; Javed et al., 2018; Azeem et al., 2017a). There is a need for further studies in order to understand the physiological basis and mechanism of recovery from water-stress. A method to assess the restriction of photosynthetic processes during water-stress time scales and then recovery has been suggested by Grassi and Magnani (2005), who recorded the results by dividing the total limitation into 3-parts: stomatal closure, diffusion of mesophyll and carboxylation activity. These outcomes highlight the importance of mesophyll conductance during stress periods and for further research, it suggests an important involvement in the overall plants adaptation to drought-stress. Additional short-term experiments on water stress revealed a reduction of mesophyll conductance (Galmés et al., 2007), indicating a general trend of stress and afterwards exhibits high resistance during rewatering. However, Badger and Price (1994) and Gillon and Yakir (2000) suggested that CA activity helps for regulation of mesophyll conductance during stress and facilitating diffusion of $\mathrm{CO}_{2}$ at cellular level, and shows recovery (Flexas et al., 2008). Campomanesia adamantinum O. Berg, a salt tolerate plant, subjected to water deficit condition and rewatering which is done on day 31 from the onset of suspension of irrigation. The $S_{g}$ and $T_{R}$ began to drop from the $23^{\text {rd }}$ day to $31^{\text {st }}$-day and photosynthetic rate approached to zero as $0.2851 \mathrm{~mol} \mathrm{~m}^{-2} \mathrm{~s}^{-1}$. Therefore, WUE and Rubisco carboxylation activity are also reached to zero values. Subsequently, plants are rewatered to regain photosynthetic metabolism (Junglos et al., 2016). According to 
Yousfi et al. (2016), there had been a small recovery after rewatering in some species of Medicago laciniata $L$. as a result of severe drought stress. During rewatering phase, the plants recovered their photosynthetic metabolism, with consequent increase rate of $S_{\mathrm{g}}$, $\mathrm{T}_{\mathrm{R}}$ and WUE (Fig. 2).

A small contribution is found in this aspect of study by Galle et al. (2009) in tobacco (Nicotiana sylvestris) and Flexas et al. (2009) for hybrid Richter-110 (Vitis berlandieri $\times$ Vitis rupestris), focusing on reduction of $P_{N}$ under stress followed by rewatering to persuade recovery. In summary, the present literature strongly supports the important of rewatering and recovery of physiological parameters during rewatering as shown in Figures 2 and 3.
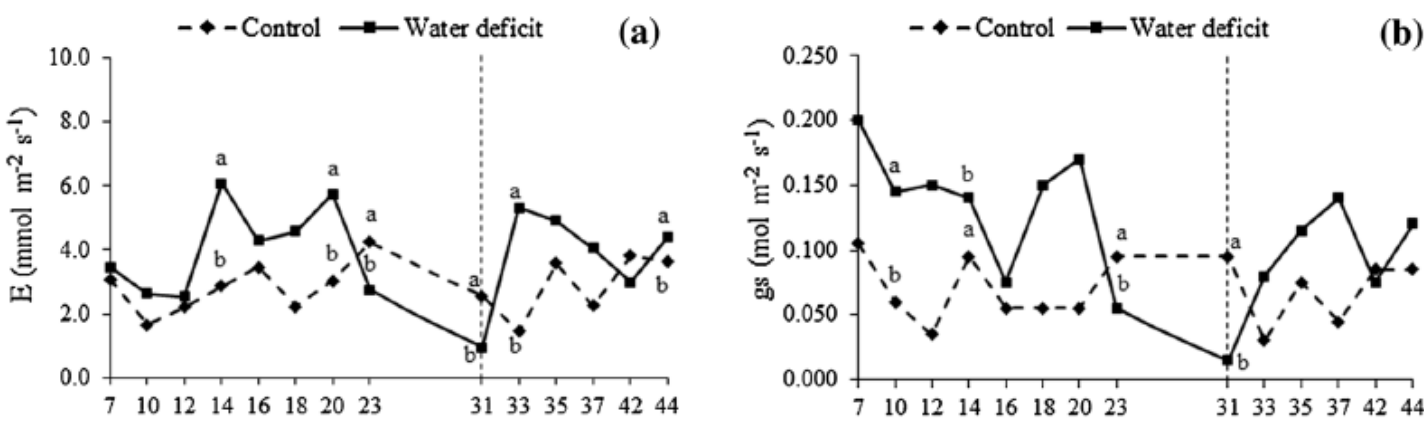

(c)
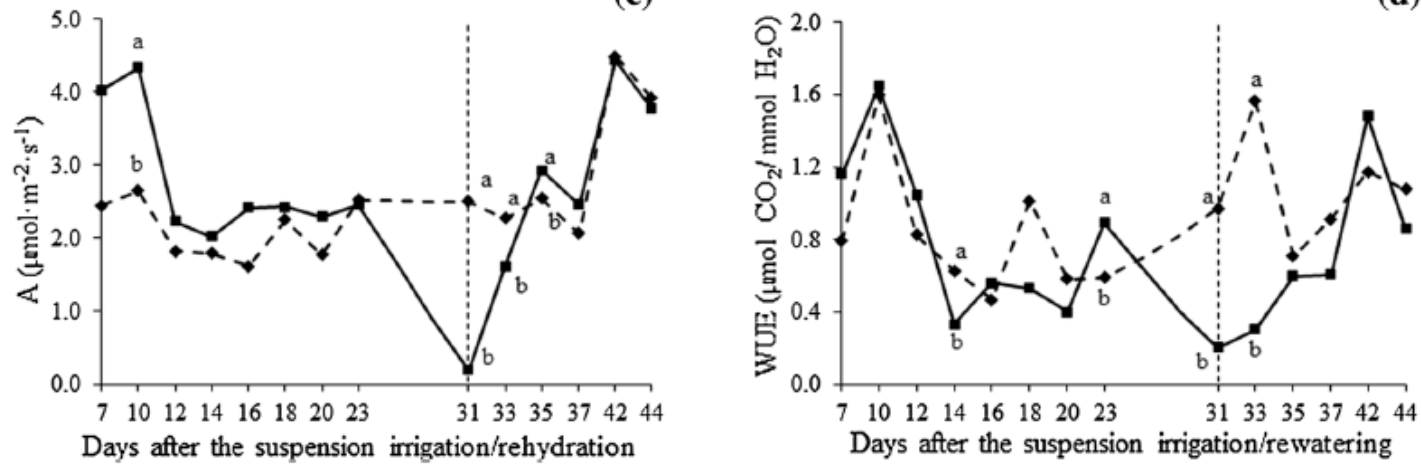

Figure 2. Transpiration $(T R=E)(a)$, stomatal conductance $(S g=g S)(b)$, photosynthetic rate $(P N=A)(c)$, and water-use efficiency $(W U E)(d)$ during different intervals when

Campomanesia adamantium is grown in well-watered and water deficit condition (Junglos et al., 2016)

\section{Dilution of salt water}

Generally, plants exhibit different physiological responses when subjected to slight, moderate and high salt stress. Many works have been done by researchers to check the response of different crops by using saline water (Turhan et al., 2014; Al-Harbi et al., 2015; Rameshwaran et al., 2016; Zhang et al., 2016; Martinez et al., 2018; de Cássia Alves et al., 2018; El-Mogy et al., 2018; Rodriguez-Ortega et al., 2017). Rewatering facilitates a positive response for plant water status and plant growth development. Over the last few years, many researchers have addressed the reaction of photosynthesis to rewatering after water-stress, which highlights the influence of salt stress and subsequent rewatering with pure water on plants (Hura et al., 2006; Pérez-Pérez et al., 
2007; Luo et al., 2008; Gomes et al., 2008). But none of these studies reflect the dilution of salted water or rewatering with saline water. However, by doing so it is possible to utilize the saline water resources for agricultural activities.

Moderately, salt-tolerant crop can be irrigated by diluted saline water, when freshwater resources are limited. Diluted saline water becomes the readily available water for irrigation of plants. The order of dilution or re-watering is that the plants are suffering in high concentration of salts irrigated with moderate concentration of salts. In another sense, at threshold levels, the plant can be re-watered with diluted saline water (Javed et al., 2017). The regime is considered very important in plants to adopt the behavior of salt tolerance under drought stress environment, at which $P_{N}$ is sustained and recovered throughout the phases of water-stress (Chartzoulakis et al., 2002b). Junglos et al. (2016) rewatered Campomanesia adamantinum O. Berg plants when photosynthetic rate approached to zero. Therefore, it is essential for plants to be rewatered with diluted saline water prior to their wilting stages instead of applying direct saline-water to crops.

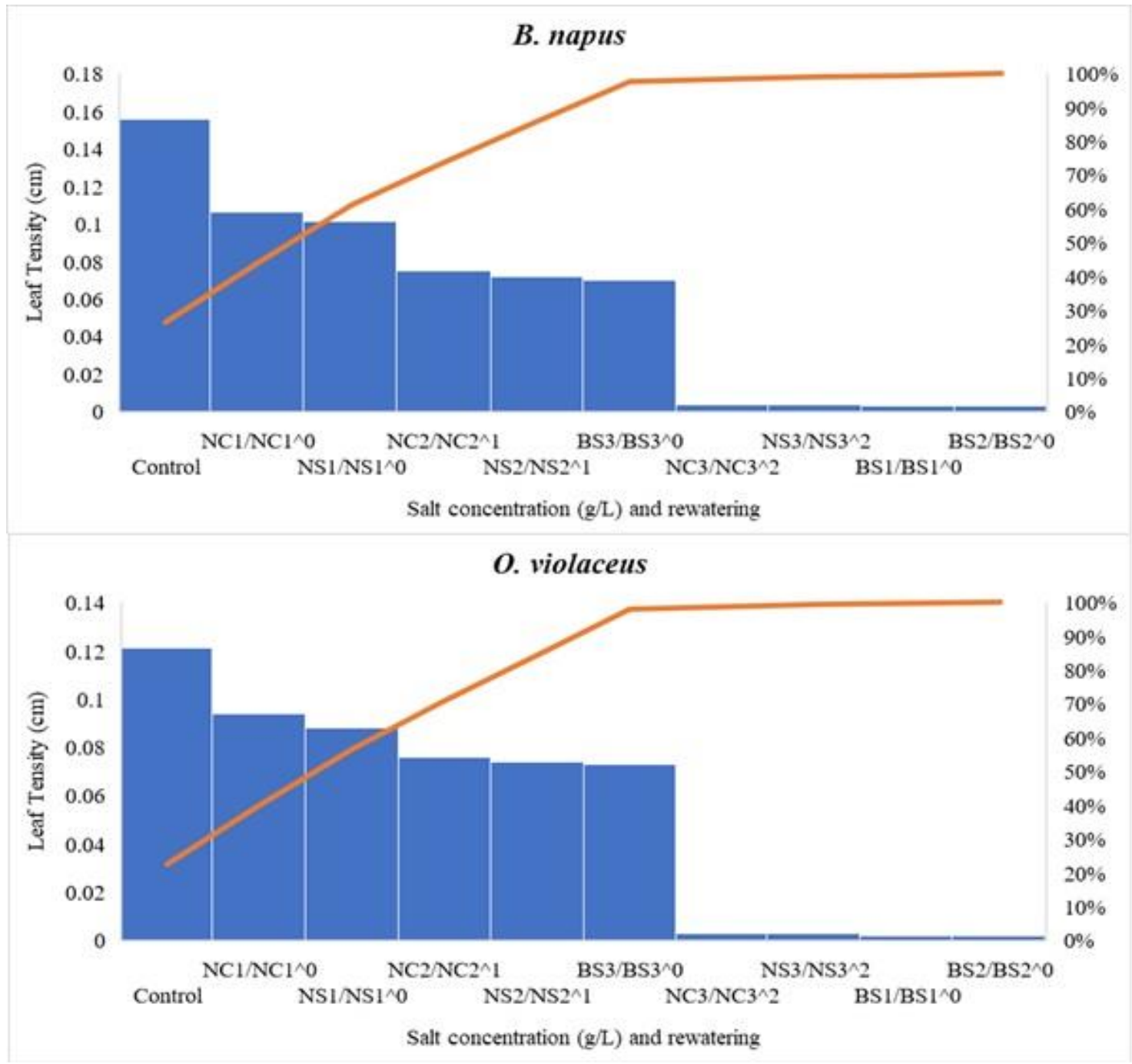

Figure 3. Effect of salt stress on leaf tensity of Brassica napus and Orychophragmus violaceus under salt stress conditions followed by recovery during re-watering (Javed et al., 2017) 
This review thus suggested new insights in the agricultural field to design irrigation scheduling by considering the salt tolerant capability of crops as explained well in Figure 4.

Afterwards, irrigation water use efficiency can be ascertained through the application of precise irrigation quantity, based on the rewatering point. It would be an affirmative step, if implemented, to increase crop production in salt affected regions. It will aid in maintaining the stability between the irrigation amount and optimum crop water consumption and effective utilization of salt water, thereby reducing the everlasting demand fresh water resources for irrigation purposes.

\section{Salt stress}

Low salts concentrations Moderate salts concentrations High salts concentrations

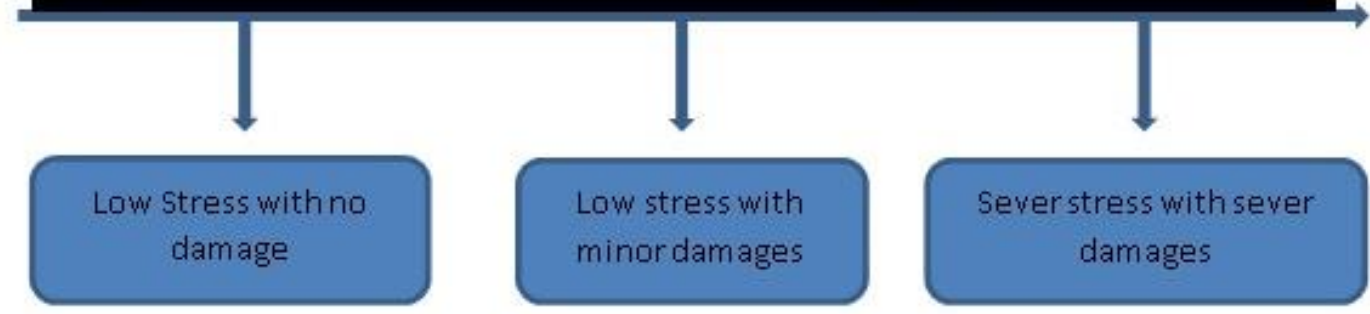

Re-watering

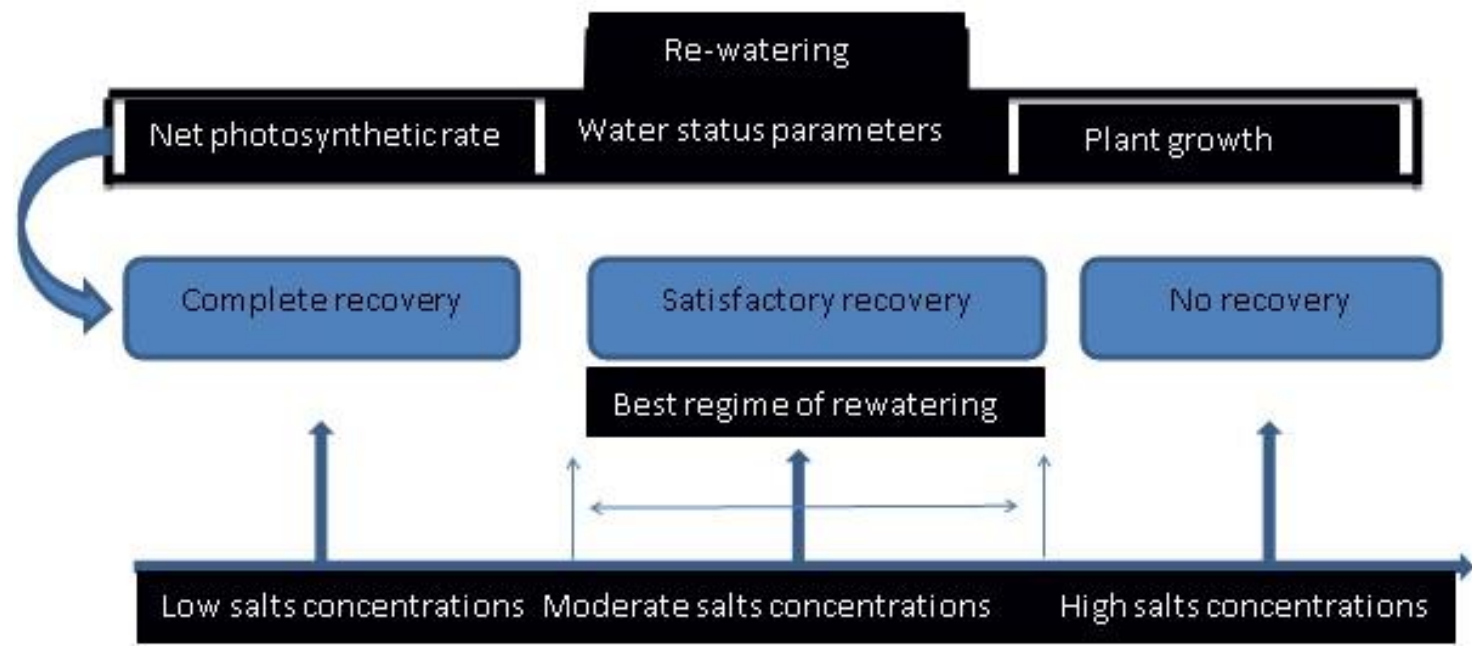

Figure 4. Irrigation scheduling by considering the salt tolerant capability of crops

\section{Conclusion}

This review briefly described the stress effects with respect to tolerance and physiological performances of plants. The review provides information for precise theoretical and practical irrigation based on physiological and electrophysiological characteristics. Efforts have been made to link the relative tolerance of several plant species to salt stress and subsequent rewatering with regard to toxicity under stress and their recoveries after rewatering. Present facts offer some strategies to counteract salt stress in crops through rewatering. Hence this review affirms the promising future of increasing crop production even under saline conditions. However, the vast majorities of research have focused on stress responses based on irrigation of plants. Plant 
response to stresses and then rewatering with saline water is a good approach in the field of saline irrigation and is a boon for regions where fresh water resources are limited. Therefore, the effect of salinity in plant could be reduced by diluting the saline irrigation (re-watering) response to threshold growth and photosynthetic values. Application of dilution of saline irrigation could be helpful to save water resources, maintain crop productivity even in stressful environments and reduces irrigation cost. It is recommended based on findings of this review; short experiment in controlled environment can be done to determine the dilution point for re-watering of different crops before wilting. Afterwards, this information can be utilized for irrigation of open field crops with diluted water.

Acknowledgements. We would like to acknowledge that this work was supported by the State Key Research Development Program of China (2017YFC1200103). The National Natural Science Foundation of China (31570414, 31770446), Project Funded by the Priority Academic Program Development of Jiangsu Higher Education Institutions (PAPD), Jiangsu Collaborative Innovation Center of Technology and Material of Water Treatment.

\section{REFERENCES}

[1] Abraham, N., Hema, P., Saritha, E., Subramannian, S. (2000): Irrigation automation based on soil electrical conductivity and leaf temperature. - Agricultural Water Management 45: 145-157.

[2] Ahmad, S., Wahid, A., Rasul, E., Wahid, A. (2005): Comparative morphological and physiological responses of green gram genotypes to salinity applied at different growth stages. - Botanical Bulletin of Academia Sinica 46: 135-142.

[3] Al-Harbi, A. R., Al-Omran, A. M., Alenazi, M. M., Wahb-Allah, M. A. (2015): Salinity and deficit irrigation influence tomato growth, yield and water use efficiency at different developmental stages. - International Journal of Agriculture, Biology 17(2): 241-250.

[4] Anjum, S. A., Xie, X.-Y., Wang, L.-C., Saleem, M. F., Man, C., Lei, W. (2011): Morphological, physiological and biochemical responses of plants to drought stress. African Journal of Agricultural Research 6: 2026-2032.

[5] Ashraf, M., Harris, P. (2013): Photosynthesis under stressful environments: an overview. - Photosynthetica 51: 163-190.

[6] Ashraf, M., Shahbaz, M. (2003): Assessment of genotypic variation in salt tolerance of early CIMMYT hexaploid wheat germplasm using photosynthetic capacity and water relations as selection criteria. - Photosynthetica 41: 273-280.

[7] Azeem, A., Wu, Y., Javed, Q., Xing, D., Ullah, I., Kumi, F. (2017a): Response of okra based on electrophysiological modeling under salt stress and re-watering. - Bioscience Journal 33.

[8] Azeem, A., Wu, Y., Xing, D., Javed, Q., Ullah, I. (2017b): Photosynthetic response of two okra cultivars under salt stress and re-watering. - Journal of Plant Interactions 12: 67-77.

[9] Azevedo Neto, A. D. D., Prisco, J. T., Enéas-Filho, J., Lacerda, C. F. D., Silva, J. V., Costa, P. H. A. D., Gomes-Filho, E. (2004): Effects of salt stress on plant growth, stomatal response and solute accumulation of different maize genotypes. - Brazilian Journal of Plant Physiology 16: 31-38.

[10] Aziz, I., Khan, M. A. (2001): Effect of Seawater on the Growth, Ion Content and Water Potential of Rhizophora mucronata Lam. - Journal of Plant Research 114: 369-373.

[11] Badger, M. R., Price, G. D. (1994): The role of carbonic anhydrase in photosynthesis. Annual Review of Plant Biology 45: 369-392. 
[12] Baeza, P., Sánchez-De-Miguel, P., Centeno, A., Junquera, P., Linares, R., Lissarrague, J. R. (2007): Water relations between leaf water potential, photosynthesis and agronomic vine response as a tool for establishing thresholds in irrigation scheduling. - Scientia Horticulturae 114: 151-158.

[13] Bayuelo-Jimenez, J. S., Craig, R., Lynch, J. P. (2002a): Salinity tolerance of species during germination and early seedling growth. - Crop Science 42: 1584-1594.

[14] Bayuelo-Jimenez, J. S., Debouck, D. G., Lynch, J. P. (2002b): Salinity tolerance in Phaseolus species during early vegetative growth. (Plant Genetic Resources). - Crop Science 42: 2184-2193.

[15] Bernard, N., Zebic, O., Deloire, A. (2004): Estimation de l'état hydrique de la vigne par la mesure de la température foliaire: Un outil au service des professionnels. - Le Progrès Agricole et Viticole 121: 539-542.

[16] Bhatt, M. J., Patel, A. D., Bhatti, P. M., Pandey, A. N. (2008): Effect of soil salinity on growth, water status and nutrient accumulation in seedlings of Ziziphus mauritiana (rhamnaceae). - Journal of Fruit Ornamental and Plant Research 16: 383-401.

[17] Biswas, A. K. (2008): Integrated water resources management: is it working? - Water Resources Development 24: 5-22.

[18] Boughalleb, F., Abdellaoui, R., Brahim, N. B., Neffati, M. (2016a): Growth, photosynthesis, water use efficiency, and osmoregulation of the wild species Astragalus gombiformis Pomel. - Under water deficit. Brazilian Journal of Botany 39: 147-156.

[19] Boughalleb, F., Abdellaoui, R., Brahim, N. B., Neffati, M. (2016b): Growth, photosynthesis, water use efficiency, and osmoregulation of the wild species Astragalus gombiformis Pomel. - Under water deficit. Brazilian Journal of Botany 39: 147-156.

[20] Bustan, A., Sagi, M., De Malach, Y., Pasternak, D. (2004): Effects of saline irrigation water and heat waves on potato production in an arid environment. - Field Crops Research 90: 275-285.

[21] Carter, C., Grieve, C., Poss, J. (2005): Salinity effects on emergence, survival, and ion accumulation of Limonium perezii. - Journal of Plant Nutrition 28: 1243-1257.

[22] Chartzoulakis, K., Loupassaki, M., Bertaki, M., Androulakis, I. (2002a): Effects of NaCl salinity on growth, ion content and CO 2 assimilation rate of six olive cultivars. Scientia Horticulturae 96: 235-247.

[23] Chartzoulakis, K., Patakas, A., Kofidis, G., Bosabalidis, A., Nastou, A. (2002b): Water stress affects leaf anatomy, gas exchange, water relations and growth of two avocado cultivars. - Scientia Horticulturae 95: 39-50.

[24] Chaves, M., Flexas, J., Pinheiro, C. (2009): Photosynthesis under drought and salt stress: regulation mechanisms from whole plant to cell. - Annals of Botany 103: 551-560.

[25] Chen, C., Tao, C., Peng, H., Ding, Y. (2007): Genetic analysis of salt stress responses in asparagus bean (Vigna unguiculata (L.) ssp. sesquipedalis Verdc.). - Journal of Heredity 98: 655-665.

[26] Cifre, J., Bota, J., Escalona, J., Medrano, H., Flexas, J. (2005): Physiological tools for irrigation scheduling in grapevine (Vitis vinifera L.): An open gate to improve water-use efficiency? - Agriculture, Ecosystems \& Environment 106: 159-170.

[27] Damayanthi, M., Mohotti, A., Nissanka, S. (2011): Comparison of tolerant ability of mature field grown tea (Camellia sinensis L.) cultivars exposed to a drought stress in Passara Area. - Tropical Agricultural Research 22. DOI: 10.4038/tar.v22i1.2671.

[28] Dantas, B. F., Ribeiro, L. D. S., Aragão, C. A. (2005): Physiological response of cowpea seeds to salinity stress. - Revista Brasileira de Sementes 27: 144-148.

[29] De Cássia Alves, R., De Medeiros, A. S., Nicolau, M. C. M., De Assis Oliveira, F., Lima, L. W., Aroucha, E. M. M., Gratão, P. L. (2018): Influence of partial root-zone saline irrigation management on tomato yield and fruit quality from a potted-plant study. HortScience 53: 1326-1331. 
[30] De Swaef, T., Steppe, K., Lemeur, R. (2009): Determining reference values for stem water potential and maximum daily trunk shrinkage in young apple trees based on plant responses to water deficit. - Agricultural Water Management 96: 541-550.

[31] Deloire, A., Carbonneau, A., Wang, Z., Ojeda, H. (2004): Vine and water: a short review. - OENO One 38: 1-13.

[32] Du, T., Kang, S., Zhang, X., Zhang, J. (2014): China's food security is threatened by the unsustainable use of water resources in North and Northwest China. - Food and Energy Security 3: 7-18.

[33] Du, T., Kang, S., Zhang, J., Davies, W. J. (2015): Deficit irrigation and sustainable waterresource strategies in agriculture for China's food security. - Journal of Experimental Botany 66: 2253-2269.

[34] El-Mogy, M. M., Garchery, C., Stevens, R. (2018): Irrigation with salt water affects growth, yield, fruit quality, storability and marker-gene expression in cherry tomato. Acta Agriculturae Scandinavica, Section B - Soil \& Plant Science. DOI: 10.1080/09064710.2018.1473482.

[35] Ennahli, S., Earl, H. J. (2005): Physiological limitations to photosynthetic carbon assimilation in cotton under water stress. - Crop Science 45: 2374-2382.

[36] Flexas, J., Bota, J., Loreto, F., Cornic, G., Sharkey, T. (2004): Diffusive and metabolic limitations to photosynthesis under drought and salinity in C3 plants. - Plant Biology 6: 269-279.

[37] Flexas, J., Bota, J., Galmes, J., Medrano, H., Ribas-Carbó, M. (2006): Keeping a positive carbon balance under adverse conditions: responses of photosynthesis and respiration to water stress. - Physiologia Plantarum 127: 343-352.

[38] Flexas, J., Ribas-Carbo, M., Diaz-Espejo, A., Galmes, J., Medrano, H. (2008): Mesophyll conductance to $\mathrm{CO} 2$ : current knowledge and future prospects. - Plant, Cell \& Environment 31: 602-621.

[39] Flexas, J., Barón, M., Bota, J., Ducruet, J.-M., Gallé, A., Galmés, J., Jiménez, M., Pou, A., Ribas-Carbó, M., Sajnani, C. (2009): Photosynthesis limitations during water stress acclimation and recovery in the drought-adapted Vitis hybrid Richter-110 (V. berlandieri $\times$ V. rupestris). - Journal of Experimental Botany 60: 2361-2377.

[40] Flowers, T., Yeo, A. (1995): Breeding for salinity resistance in crop plants: where next? Functional Plant Biology 22: 875-884.

[41] Galle, A., Florez-Sarasa, I., Tomas, M., Pou, A., Medrano, H., Ribas-Carbo, M., Flexas, J. (2009): The role of mesophyll conductance during water stress and recovery in tobacco (Nicotiana sylvestris): acclimation or limitation? - Journal of Experimental Botany 60: 2379-2390.

[42] Gallé, A., Haldimann, P., Feller, U. (2007): Photosynthetic performance and water relations in young pubescent oak (Quercus pubescens) trees during drought stress and recovery. - New Phytologist 174: 799-810.

[43] Galmés, J., Medrano, H., Flexas, J. (2007): Photosynthetic limitations in response to water stress and recovery in Mediterranean plants with different growth forms. - New Phytologist 175: 81-93.

[44] Gama, P., Inanaga, S., Tanaka, K., Nakazawa, R. (2007): Physiological response of common bean (Phaseolus vulgaris L.) seedlings to salinity stress. - African Journal of Biotechnology 6(2).

[45] Gama, P. B. S., Tanaka, K., Eneji, A. E., Eltayeb, A. E., Siddig, K. E. (2009): Saltinduced stress effects on biomass, photosynthetic rate, and reactive oxygen speciesscavenging enzyme accumulation in common bean. - Journal of Plant Nutrition 32: 837854.

[46] Garcia, L. E. (2008): Integrated water resources management: a 'small'step for conceptualists, a giant step for practitioners. - Water Resources Development 24: 23-36.

[47] Gillon, J. S., Yakir, D. (2000): Internal conductance to CO2 diffusion and C18OO discrimination in C3 leaves. - Plant Physiology 123: 201-214. 
[48] Gomes, F. P., Oliva, M. A., Mielke, M. S., De Almeida, A.-A. F., Leite, H. G., Aquino, L. A. (2008): Photosynthetic limitations in leaves of young Brazilian Green Dwarf coconut (Cocos nucifera L. 'nana') palm under well-watered conditions or recovering from drought stress. - Environmental and Experimental Botany 62: 195-204.

[49] Gómez-Del-Campo, M., Baeza, P., Ruiz, C., Sotés, V., Lissarrague, J. (2015): Effect of previous water conditions on vine response to rewatering. - VITIS-Journal of Grapevine Research 46: 51.

[50] Gorai, M., Hachef, A., Neffati, M. (2010): Differential responses in growth and water relationship of Medicago sativa (L.) cv. Gabès and Astragalus gombiformis (Pom.) under water-limited conditions. - Emirates Journal of Food and Agriculture 22: 1.

[51] Grassi, G., Magnani, F. (2005): Stomatal, mesophyll conductance and biochemical limitations to photosynthesis as affected by drought and leaf ontogeny in ash and oak trees. - Plant, Cell \& Environment 28: 834-849.

[52] Guliyev, N., Bayramov, S., Babayev, H. (2008): Effect of Water Deficit on RUBISCO and carbonic Anhydrase Activities in Different Wheat Genotypes. - In: Allen, J. F. et al. (eds.) Photosynthesis. Energy from the Sun. Springer, Dordrecht.

[53] Habib, N., Ashraf, M., Ali, Q., Perveen, R. (2012): Response of salt stressed okra (Abelmoschus esculentus Moench) plants to foliar-applied glycine betaine and glycine betaine containing sugarbeet extract. - South African Journal of Botany 83: 151-158.

[54] Hacisalihoglu, G., Hart, J. J., Wang, Y.-H., Cakmak, I., Kochian, L. V. (2003): Zinc efficiency is correlated with enhanced expression and activity of zinc-requiring enzymes in wheat. - Plant Physiology 131: 595-602.

[55] Hayat, S., Ali, B., Hasan, S. A., Ahmad, A. (2007): Effect of 28-homobrassinolide on salinity-induced changes in Brassica juncea. - Turkish Journal of Biology 31: 141-146.

[56] Heenan, D., Lewin, L., Mccaffery, D. (1988): Salinity tolerance in rice varieties at different growth stages. - Animal Production Science 28: 343-349.

[57] Henry, R. P. (1996): Multiple roles of carbonic anhydrase in cellular transport and metabolism. - Annual Review of Physiology 58: 523-538.

[58] Hu, H., Boisson-Dernier, A., Israelsson-Nordström, M., Böhmer, M., Xue, S., Ries, A., Godoski, J., Kuhn, J. M., Schroeder, J. I. (2011): Carbonic anhydrases are upstream regulators of CO2-controlled stomatal movements in guard cells. - Nature Cell Biology 13: 734-734.

[59] Hu, L., Wang, Z., Huang, B. (2009): Photosynthetic responses of bermudagrass to drought stress associated with stomatal and metabolic limitations. - Crop Science 49: 1902-1909.

[60] Hura, T., Grzesiak, S., Hura, K., Grzesiak, M., Rzepka, A. (2006): Differences in the physiological state between triticale and maize plants during drought stress and followed rehydration expressed by the leaf gas exchange and spectrofluorimetric methods. - Acta Physiologiae Plantarum 28: 433-443.

[61] Intrigliolo, D., Castel, J., Perez, D. (2004): Water relations of field grown drip irrigated Tempranillo grapevines. - VII International Symposium on Grapevine Physiology and Biotechnology 689: 317-324.

[62] Jamil, M., Rehman, S., Rha, E. (2007): Salinity effect on plant growth, PSII photochemistry and chlorophyll content in sugar beet (Beta Vulgaris L.) and cabbage (Brassica Oleracea Capitata L.). - Pakistan Journal of Botany 39: 753-760.

[63] Javed, Q., Wu, Y., Xing, D., Azeem, A., Ullah, I., Zaman, M. (2017): Re-watering: An effective measure to recover growth and photosynthetic characteristics in salt-stressed Brassica napus L. - Chilean Journal of Agricultural Research 77: 78-86.

[64] Javed, Q., Wu, Y., Xing, D., Ullah, I., Azeem, A., Rasool, G. (2018): Salt-induced effects on growth and photosynthetic traits of Orychophragmus violaceus and its restoration through re-watering. - Brazilian Journal of Botany 41: 29-41.

[65] Jouyban, Z. (2012): The effects of salt stress on plant growth. - Tech J Engin \& App Sci 2: $7-10$. 
[66] Junglos, F. S., Junglos, M. S., Dresch, D. M., Pereira, N. S., Kodama, F. M., De Paula Quintão Scalon, S. (2016): Recovery of the photosynthetic capacity of Campomanesia adamantium (Myrtaceae) after water deficit. - Brazilian Journal of Botany 39: 541-546.

[67] Kalapos, T. (1994): Leaf water potential-leaf water deficit relationship for ten species of a semiarid grassland community. - Plant and Soil 160: 105-112.

[68] Kao, W.-Y., Tsai, T.-T., Tsai, H.-C., Shih, C.-N. (2006): Response of three Glycine species to salt stress. - Environmental and Experimental Botany 56: 120-125.

[69] Kapoor, K., Srivastava, A. (2010): Assessment of salinity tolerance of Vinga mungo var. $\mathrm{Pu}-19$ using ex vitro and in vitro methods. - Asian J. Biotechnol 2: 73-85.

[70] Kaymakanova, M., Stoeva, N. (2008): Physiological reaction of bean plants (Phaseolus vulg. L.) to salt stress. - General and Applied Plant Physiology (Special Issue) 34(3-4): 177-188.

[71] Kicheva, M., Lazova, G. (1998): Response of carbonic anhydrase to polyethylene glycolmediated water stress in wheat. - Photosynthetica 34: 133-135.

[72] Koide, R. T. (1991): Nutrient supply, nutrient demand and plant response to mycorrhizal infection. - New Phytologist 117: 365-386.

[73] Läuchli, A., Grattan, S. (2007): Plant Growth and Development under Salinity Stress. In: Jenks, M. A. et al. (eds.) Advances in Molecular Breeding Toward Drought and Salt Tolerant Crops. Springer, Dordrecht.

[74] Lee, G., Carrow, R. N., Duncan, R. R. (2005): Growth and water relation responses to salinity stress in halophytic seashore paspalum ecotypes. - Scientia Horticulturae 104: 221-236.

[75] Lopes, C. M. (1998): Relationships between leaf water potential and photosynthetic activity of field-grown grapevines under a Mediterranean environment. - I ISHS Workshop on Water Relations of Grapevines 493: 287-292.

[76] Luo, H., Zhang, Y., Zhang, W., Bai, H., He, Z., Du, M., Zhang, H. (2008): Effects of Rewatering after Drought Stress on Photosynthesis and Yield during Flowering and BollSetting Stage of Cotton Under-Mulch-Drip Irrigation in Xinjiang. - Acta Agronomica Sinica 34: 171.

[77] Lutz, W., Butz, W. P., Samir, K. E. (2017): World Population \& Human Capital in the Twenty-First Century: An Overview. - Oxford University Press, Oxford.

[78] Maggio, A., De Pascale, S., Ruggiero, C., Barbieri, G. (2005): Physiological response of field-grown cabbage to salinity and drought stress. - European Journal of Agronomy 23: 57-67.

[79] Mahlooji, M., Sharifi, R. S., Razmjoo, J., Sabzalian, M., Sedghi, M. (2018): Effect of salt stress on photosynthesis and physiological parameters of three contrasting barley genotypes. - Photosynthetica 56: 549-556.

[80] Mansour, M. M. F., Salama, K. H. (2004): Cellular basis of salinity tolerance in plants. Environmental and Experimental Botany 52: 113-122.

[81] Martinez, V., Nieves-Cordones, M., Lopez-Delacalle, M., Rodenas, R., Mestre, T. C., Garcia-Sanchez, F., Rubio, F., Nortes, P. A., Mittler, R., Rivero, R. M. (2018): Tolerance to stress combination in tomato plants: new insights in the protective role of melatonin. Molecules 23: 535.

[82] Mathur, N., Singh, J., Bohra, S., Bohra, A., Vyas, A. (2006): Biomass production, productivity and physiological changes in moth bean genotypes at different salinity levels. - American Journal of Plant Physiology 1: 210-213.

[83] Meloni, D. A., Oliva, M. A., Ruiz, H. A., Martinez, C. A. (2001): Contribution of proline and inorganic solutes to osmotic adjustment in cotton under salt stress. - Journal of Plant Nutrition 24: 599-612.

[84] Memon, S. A., Hou, X., Wang, L. J. (2010): Morphological analysis of salt stress respose of pak choi. - Electronic Journal of Environmental, Agricultural \& Food Chemistry 9: 248-254. 
[85] Mishra, S., Das, A. (2003): Effect of $\mathrm{NaCl}$ on leaf salt secretion and antioxidative enzyme level in roots of a mangrove, Aegiceras corniculatum. - Indian Journal of Experimental Biology 41: 160-166.

[86] Miyashita, K., Tanakamaru, S., Maitani, T., Kimura, K. (2005): Recovery responses of photosynthesis, transpiration, and stomatal conductance in kidney bean following drought stress. - Environmental And Experimental Botany 53: 205-214.

[87] Mosaffa, H. R., Sepaskhah, A. R. (2018): Performance of irrigation regimes and water salinity on winter wheat as influenced by planting methods. - Agricultural Water Management. https://doi.org/10.1016/j.agwat.2018.10.027.

[88] Munira, S., Hossain, M., Zakaria, M., Ahmed, J., Islam, M. (2015): Evaluation of Potato Varieties against Salinity Stress in Bangladesh. - International Journal of Plant and Soil Science 6: 73-81.

[89] Munns, R. (2002): Comparative physiology of salt and water stress. - Plant, Cell \& Environment 25: 239-250.

[90] Munns, R. (2005): Genes and salt tolerance: bringing them together. - New Phytologist 167: 645-663.

[91] Munns, R., Tester, M. (2008): Mechanisms of salinity tolerance. - Annual Review of Plant Biology 59: 651-681.

[92] Murillo-Amador, B., Yamada, S., Yamaguchi, T., Rueda-Puente, E., Ávila-Serrano, N., García-Hernández, J., López-Aguilar, R., Troyo-Diéguez, E., Nieto-Garibay, A. (2007): Influence of calcium silicate on growth, physiological parameters and mineral nutrition in two legume species under salt stress. - Journal of Agronomy and Crop Science 193: 413421.

[93] Mustard, J., Renault, S. (2006): Response of red-osier dogwood (Cornus sericea) seedlings to $\mathrm{NaCl}$ during the onset of bud break. - Botany 84: 844-851.

[94] Nadeem, S. M., Ahmad, M., Zahir, Z. A., Javaid, A., Ashraf, M. (2014): The role of mycorrhizae and plant growth promoting rhizobacteria (PGPR) in improving crop productivity under stressful environments. - Biotechnology Advances 32: 429-448.

[95] Nangare, D., Singh, Y., Kumar, P. S., Minhas, P. (2016): Growth, fruit yield and quality of tomato (Lycopersicon esculentum Mill.) as affected by deficit irrigation regulated on phenological basis. - Agricultural Water Management 171: 73-79.

[96] Negrão, S., Schmöckel, S. M., Tester, M. (2017): Evaluating physiological responses of plants to salinity stress. - Annals of Botany 119: 1-11.

[97] Nerson, H., Paris, H. (1984): Effects of salinity on germination, seedling growth, and yield of melons. - Irrigation Science 5: 265-273.

[98] Netondo, G. W., Onyango, J. C., Beck, E. (2004): Sorghum and salinity. - Crop Science 44: 797-805.

[99] Niazi, B., Athar, M., Salim, M., Rozema, J. (2005): Growth and ionic relations of fodderbeet and seabeet under saline environments. - International Journal of Environmental Science \& Technology 2: 113-120.

[100] Nohong, B., Nompo, S. (2015): Effect of water stress on growth, yield, proline and soluble sugars contents of Signal grass and Napier grass species. - American-Eurasian Journal of Sustainable Agriculture 9: 14-21.

[101] Parida, A. K., Das, A. B. (2005): Salt tolerance and salinity effects on plants: a review. Ecotoxicology and Environmental Safety 60: 324-349.

[102] Parida, A. K., Das, A., Mittra, B. (2004): Effects of salt on growth, ion accumulation, photosynthesis and leaf anatomy of the mangrove, Bruguiera parviflora. - Trees 18: 167174.

[103] Pérez-Pérez, J., Syvertsen, J. P., Botía, P., García-Sánchez, F. (2007): Leaf water relations and net gas exchange responses of salinized Carrizo citrange seedlings during drought stress and recovery. - Annals of Botany 100: 335-345.

[104] Qados, A. M. A. (2011): Effect of salt stress on plant growth and metabolism of bean plant Vicia faba (L.). - Journal of the Saudi Society of Agricultural Sciences 10: 7-15. 
[105] Rady, M. O., Semida, W. M., El-Mageed, T. A. A., Hemida, K. A., Rady, M. M. (2018): Up-regulation of antioxidative defense systems by glycine betaine foliar application in onion plants confer tolerance to salinity stress. - Scientia Horticulturae 240: 614-622.

[106] Rahnama, A., Poustini, K., Tavakkol-Afshari, R., Tavakoli, A. (2010): Growth and stomatal responses of bread wheat genotypes in tolerance to salt stress. - International Journal of Biology and Life Sciences 6: 216-221.

[107] Rameshwaran, P., Tepe, A., Yazar, A., Ragab, R. (2016): Effects of drip-irrigation regimes with saline water on pepper productivity and soil salinity under greenhouse conditions. - Scientia Horticulturae 199: 114-123.

[108] Riccardi, M., Pulvento, C., Lavini, A., D'andria, R., Jacobsen, S. E. (2014): Growth and ionic content of quinoa under saline irrigation. - Journal of Agronomy And Crop Science 200: 246-260.

[109] Rodriguez-Ortega, W., Martinez, V., Rivero, R., Camara-Zapata, J., Mestre, T., GarciaSanchez, F. (2017): Use of a smart irrigation system to study the effects of irrigation management on the agronomic and physiological responses of tomato plants grown under different temperatures regimes. - Agricultural Water Management 183: 158-168.

[110] Rui, L., Wei, S., Muxiang, C., Chengjun, J., Min, W., Boping, Y. (2009): Leaf anatomical changes of Bruguiera gymnorrhiza seedlings under salt stress. - Journal of Tropical and Subtropical Botany 17: 169-175.

[111] Ruiz-Sýnchez, M., Torrecillas, A., Del Amor, F., Leon, A., Abrisqueta, J. (1988): Leaf water potential and leaf conductance during the growing season in almond trees under different irrigation regimes. - Biologia Plantarum 30: 327-332.

[112] Saibo, N. J., Lourenço, T., Oliveira, M. M. (2009): Transcription factors and regulation of photosynthetic and related metabolism under environmental stresses. - Annals of Botany 103: 609-623.

[113] Salón, J. L., Chirivella, C., Castel, J. R. (2005): Response of cv. Bobal to timing of deficit irrigation in Requena, Spain: water relations, yield, and wine quality. - American Journal of Enology and Viticulture 56: 1-8.

[114] Sato, T., Abdalla, O. S., Oweis, T. Y., Sakuratani, T. (2006): The validity of predawn leaf water potential as an irrigation-timing indicator for field-grown wheat in northern Syria. Agricultural Water Management 82: 223-236.

[115] Sayed, O. (2003): Chlorophyll fluorescence as a tool in cereal crop research. Photosynthetica 41: 321-330.

[116] Shahbaz, M., Ashraf, M. (2013): Improving salinity tolerance in cereals. - Critical Reviews in Plant Sciences 32: 237-249.

[117] Siddiqui, Z. S., Khan, M. A., Kim, B.-G., Huang, J.-S., Kwon, T.-R. (2008): Physiological responses of Brassica napus genotypes to combined drought and salt stress. - Plant Stress 2: 78-83.

[118] Sikuku, P., Netondo, G., Onyango, J., Musyimi, D. (2010): Chlorophyll fluorescence, protein and chlorophyll content of three nerica rainfed rice varieties under varying irrigation regimes. - ARPN Journal of Agricultural and Biological Science 5: 19-25.

[119] Singh, A. (2018): Salinization of agricultural lands due to poor drainage: a viewpoint. Ecological Indicators 95: 127-130.

[120] Sofo, A., Dichio, B., Xiloyannis, C., Masia, A. (2004): Effects of different irradiance levels on some antioxidant enzymes and on malondialdehyde content during rewatering in olive tree. - Plant Science 166: 293-302.

[121] Souza Filho, A., Alves, S., Figueiredo, F. (2003): Allelopathic effects of calopo according to its age and to seed density of the receiver plant. - Planta Daninha 21: 211-218.

[122] Taffouo, V., Wamba, O., Youmbi, E., Nono, G., Akoa, A. (2010): Growth, yield, water status and ionic distribution response of three bambara groundnut (Vigna subterranea $(L$.) Verdc.) landraces grown under saline conditions. - International Journal of Botany 6: 5358 . 
[123] Taffouo, V. D., Kouamou, J. K., Ngalangue, L. M. T., Ndjeudji, B. A. N., Akoa, A. (2009): Effects of salinity stress on growth, ions partitioning and yield of some cowpea (Vigna unguiculata L. Walp.) cultivars. - International Journal of Botany 5: 135-143.

[124] Tajbakhsh, M., Zhou, M., Chen, Z., Mendham, N. (2006): Physiological and cytological response of salt-tolerant and non-tolerant barley to salinity during germination and early growth. - Animal Production Science 46: 555-562.

[125] Tavallali, V., Rahemi, M., Maftoun, M., Panahi, B., Karimi, S., Ramezanian, A., Vaezpour, M. (2009): Zinc influence and salt stress on photosynthesis, water relations, and carbonic anhydrase activity in pistachio. - Scientia Horticulturae 123: 272-279.

[126] Tester, M., Bacic, A. (2005): Abiotic stress tolerance in grasses. From model plants to crop plants. - Plant Physiology 137: 791-793.

[127] Tort, N., Turkyilmaz, B. (2004): A physiological investigation on the mechanisms of salinity tolerance in some barley culture forms. - JFS 27: 1-16.

[128] Turan, M. A., Katkat, V., Taban, S. (2007): Salinity-induced stomatal resistance, proline, chlorophyll and ion concentrations of bean. - International Journal of Agricultural Research 2: 483-488.

[129] Turhan, A., Kuşçu, H., Özmen, N., Demir, A. O. (2014): The effect of different salinity levels on the yield and some quality parameters of garlic (Allium sativum L.). - Journal of Agricultural Sciences (Turkey) 20(3): 280-287.

[130] Turner, N. C. (1988): Measurement of plant water status by the pressure chamber technique. - Irrigation Science 9: 289-308.

[131] Ullah, I., Hanping, M., Chuan, Z., Javed, Q., Azeem, A. (2017): Optimization of irrigation and nutrient concentration based on economic returns, substrate salt accumulation and water use efficiency for tomato in greenhouse. - Archives of Agronomy and Soil Science 63: 1748-1762.

[132] Vilagrosa, A., Bellot, J., Vallejo, V., Gil-Pelegrín, E. (2003): Cavitation, stomatal conductance, and leaf dieback in seedlings of two co-occurring Mediterranean shrubs during an intense drought. - Journal of Experimental Botany 54: 2015-2024.

[133] Vos, J., Groenwold, J. (1989): Genetic differences in water-use efficiency, stomatal conductance and carbon isotope fractionation in potato. - Potato Research 32: 113-121.

[134] Wang, R., Kang, Y., Wan, S., Hu, W., Liu, S., Liu, S. (2011a): Salt distribution and the growth of cotton under different drip irrigation regimes in a saline area. - Agricultural Water Management 100: 58-69.

[135] Wang, X., Geng, S., Ri, Y.-J., Cao, D., Liu, J., Shi, D., Yang, C. (2011b): Physiological responses and adaptive strategies of tomato plants to salt and alkali stresses. - Scientia Horticulturae 130: 248-255.

[136] Wani, A. S., Ahmad, A., Hayat, S., Fariduddin, Q. (2013): Salt-induced modulation in growth, photosynthesis and antioxidant system in two varieties of Brassica juncea. Saudi Journal of Biological Sciences 20: 183-193.

[137] Williams, L., Araujo, F. (2002): Correlations among predawn leaf, midday leaf, and midday stem water potential and their correlations with other measures of soil and plant water status in Vitis vinifera. - Journal of the American Society for Horticultural Science 127: 448-454.

[138] Wu, Y., Xing, D. (2012): Effect of bicarbonate treatment on photosynthetic assimilation of inorganic carbon in two plant species of Moraceae. - Photosynthetica 50: 587-594.

[139] Wu, Y., Wu, X., Li, P., Zhao, Y., Li, X., Zhao, X. (2005): Comparison of photosynthetic activity of Orychophragmus violaceus and oil-seed rape. - Photosynthetica 43: 299-302.

[140] Wu, Y., Li, P., Zhao, Y., Wang, J., Wu, X. (2007): Study on photosynthetic characteristics of Orychophragmus violaceus related to shade-tolerance. - Scientia Horticulturae 113: 173-176.

[141] Wu, Y., Shi, Q., Wang, K., Li, P., Xing, D., Zhu, Y., Song, Y. (2011): An Electrochemical Approach Coupled with Sb Microelectrode to Determine the Activities 
of Carbonic Anhydrase in the Plant Leaves. - In: Zeng, D. (ed.) Future Intelligent Information Systems. - Springer, Berlin.

[142] Xiloyannis, C., Dichio, B., Nuzzo, V., Celano, G. (1997): Defence strategies of olive against water stress. - III International Symposium on Olive Growing 474: 423-426.

[143] Xing, D., Wu, Y. (2012): Photosynthetic response of three climber plant species to osmotic stress induced by polyethylene glycol (PEG) 6000. - Acta Physiologiae Plantarum 34: 1659-1668.

[144] Xing, D., Wu, Y. (2015): Effects of low nutrition on photosynthetic capacity and accumulation of total $\mathrm{N}$ and $\mathrm{P}$ in three climber plant species. - Chinese Journal of Geochemistry 34: 115-122.

[145] Xing, D., Xu, X., Wu, Y., Liu, Y., Wu, Y., Ni, J., Azeem, A. (2018): Leaf tensity: a method for rapid determination of water requirement information in Brassica napus L. Journal of Plant Interactions 13: 380-387.

[146] Xu, C., Leskovar, D. (2014): Growth, physiology and yield responses of cabbage to deficit irrigation. - HortScience (Prague) 41: 138-146.

[147] Yepes, L., Chelbi, N., Vivo, J.-M., Franco, M., Agudelo, A., Carvajal, M., Del Carmen Martínez-Ballesta, M. (2018): Analysis of physiological traits in the response of Chenopodiaceae, Amaranthaceae, and Brassicaceae plants to salinity stress. - Plant Physiology and Biochemistry 132: 145-155.

[148] Yilmaz, H., Kina, A. (2008): The influence of $\mathrm{NaCl}$ salinity on some vegetative and chemical changes of strawberries (Fragaria $x$ ananssa L.). - African Journal of Biotechnology 7(18).

[149] Yousfi, N., Sihem, N., Ramzi, A., Abdelly, C. (2016): Growth, photosynthesis and water relations as affected by different drought regimes and subsequent recovery in Medicago laciniata (L.) populations. - Journal of Plant Biology 59: 33-43.

[150] Yousif, B. S., Nguyen, N. T., Fukuda, Y., Hakata, H., Okamoto, Y., Masaoka, Y., Saneoka, H. (2010): Effect of salinity on growth, mineral composition, photosynthesis and water relations of two vegetable crops; New Zealand spinach (Tetragonia tetragonioides) and water spinach (Ipomoea aquatica). - International Journal of Agriculture and Biology 12: 211-216.

[151] Zhang, L., Clarke, M., Steven, M., Jaggard, K. (2011): Spatial patterns of wilting in sugar beet as an indicator for precision irrigation. - Precision Agriculture 12: 296-316.

[152] Zhang, M., Wu, Y., Xing, D., Zhao, K., Yu, R. (2015): Rapid Measurement of Drought Resistance in Plants Based on Electrophysiological Properties. - Transactions of the ASABE 58: 1441-1446.

[153] Zhang, P., Senge, M., Dai, Y. (2016): Effects of salinity stress on growth, yield, fruit quality and water use efficiency of tomato under hydroponics system. - Reviews in Agricultural Science 4: 46-55.

[154] Zollinger, N., Koenig, R., Cerny-Koenig, T., Kjelgren, R. (2007): Relative salinity tolerance of intermountain western United States native herbaceous perennials. HortScience 42: 529-534. 